NBER WORKING PAPER SERIES

\title{
THE IMPACT OF STATE-LEVEL R\&D TAX CREDITS ON THE QUANTITY AND QUALITY OF ENTREPRENEURSHIP
}

\author{
Catherine Fazio \\ Jorge Guzman \\ Scott Stern \\ Working Paper 26099 \\ http://www.nber.org/papers/w26099 \\ NATIONAL BUREAU OF ECONOMIC RESEARCH \\ 1050 Massachusetts Avenue \\ Cambridge, MA 02138 \\ July 2019
}

We thank Evan Absher, Brian Asquith, Tim Bartik, George Erickcek, Lee Flemming, Evan Mast, and Peter Orazem, for helpful comments, as well as participants in the UpJohn Institute Conference on the Effects of State and Local Tax Incentives on Business Location Decisions, and the Kauffman Uncommon Methods and Metrics meetings. Yu-Ting Cheng and Yupeng Liu did excellent research assistantship in this project. We also acknowledge and thank the Kauffman Foundation for their support of our research agenda, including the Uncommon Methods and Metrics grant that supported this project, and we also thank the Jean Hammond (1986) and Michael Krasner (1974) Entrepreneurship Fund and the Edward B. Roberts (1957) Entrepreneurship Fund at MIT for their support. All errors and omissions are of course our own. The views expressed herein are those of the authors and do not necessarily reflect the views of the National Bureau of Economic Research.

At least one co-author has disclosed a financial relationship of potential relevance for this research. Further information is available online at http://www.nber.org/papers/w26099.ack

NBER working papers are circulated for discussion and comment purposes. They have not been peer-reviewed or been subject to the review by the NBER Board of Directors that accompanies official NBER publications.

(C) 2019 by Catherine Fazio, Jorge Guzman, and Scott Stern. All rights reserved. Short sections of text, not to exceed two paragraphs, may be quoted without explicit permission provided that full credit, including $\odot$ notice, is given to the source. 
The Impact of State-Level R\&D Tax Credits on the Quantity and Quality of Entrepreneurship Catherine Fazio, Jorge Guzman, and Scott Stern

NBER Working Paper No. 26099

July 2019

JEL No. H25,L26

\begin{abstract}
The acceleration of start-up activity is often cited as a rationale for the $R \& D$ tax credit, a key innovation policy instrument adopted increasingly by US states over the past quarter century. While there is a strong empirical base linking the $R \& D$ tax credit to increased $R \& D$ expenditures and innovation, prior work has not provided causal evidence that this policy effects the rate of formation and growth potential of new businesses. This paper combines data from the US Startup Cartography Project with the Panel Database on Incentives and Taxes to implement a difference-in-differences estimate of the impact of the R\&D tax credit on the quantity and quality-adjusted quantity of entrepreneurship. Our key finding is that the R\&D tax credit is associated with a significant long-term impact on both the overall quantity and quality-adjusted quantity of entrepreneurship, with the bulk of the effect materializing more than five years after the policy is enacted. These findings stand in contrast to an analysis of the adoption of state-level investment tax credits. There, we observe no long-term impact on the quantity of entrepreneurship but a marked decline in the rate of formation of growth-oriented startups over time. Combined with other evidence regarding the efficacy of R\&D tax credits in spurring innovative investment, our results shed light on the potential for this fiscal policy to also stimulate the formation of growth-oriented start-ups.
\end{abstract}

Catherine Fazio

Massachusetts Institute of Technology

cfazio@mit.edu

Jorge Guzman

Columbia Business School Uris Hall, 711

116th St \& Broadway

New York, NY 10027

jag2367@gsb.columbia.edu
Scott Stern

MIT Sloan School of Management

100 Main Street, E62-476

Cambridge, MA 02142

and NBER

sstern@mit.edu 


\section{Introduction}

The promotion of entrepreneurship is a central priority of regional economic development (Lerner, 2009). New firm formation plays a pivotal role in regional economic performance: the growth of young firms is the source of nearly all net new employment (Haltiwanger et al., 2013), and a high rate of local entrepreneurship serves to maintain the competitiveness of local markets (Andersson \& Henrekson, 2015). There is likewise increasing appreciation for the role that start-up firms play in the overall innovation and commercialization process (Acs et al., 2009). However, the outcomes from entrepreneurship are highly skewed, with a small number of firms accounting for the vast bulk of economic impact (Decker et al., 2014). Consequently, assessing the role of policy on entrepreneurship depends on evaluating not only its impact in terms of the number of new companies founded, but also on its potential for generating and increasing the realization of meaningful growth outcomes (Guzman \& Stern, 2016).

One of the principal instruments that policymakers use to impact entrepreneurship is tax policy. There is considerable evidence that the incentives to start and invest in the expansion of a business depends on the overall rate of taxation (Cullen \& Gordon, 2007). Indeed, an oft-cited justification for lower rates of taxation is the general encouragement of entrepreneurship (Reynolds et al., 1999; Gurley-Calvez \& Bruce, 2013; Holtz-Eakin, 2000). As the outsized role of innovation-driven start-ups in harnessing local knowledge spillovers and enhancing the comparative advantage of regions has come to the fore (Lanahan \& Feldman, 2018; Delgado, Porter \& Stern, 2015), policymakers have increasingly deployed focused tax policies such as the R\&D tax credit for dual purposes: (1) to spur investment in innovation by larger and more established companies (their original intended purpose); and (2) to encourage the formation of growth-oriented ventures and accelerate their performance (Miller \& Richard, 2010; Wu, 2008; Bartik \& Ebert, 2011).

The primary contribution of this paper is to provide novel empirical evidence regarding the impact of state $R \& D$ tax credits on the quantity, quality and performance of entrepreneurship (that is, the realization of significant growth outcomes by new firms). On the one hand, an emerging empirical literature has documented the impact of state $R \& D$ tax credits on $R \& D$ investment, innovation and overall economic performance (Wilson, 2009; Wu, 2005; Moretti \& 
Wilson, 2014; Lucking, 2019). At the same time, since the work of Cullen and Gordon (2007) and Gentry and Hubbard (2004), there has been attention towards the overall impact of the tax system on the formation of new enterprises (Bruce, 2000; Gurley-Calvez \& Bruce, 2013; Gentry \& Hubbard, 2004; Cullen \& Gordon, 2016). And, there have been a small number of studies that have linked the R\&D tax credit to the overall growth of high-technology sectors (Wu, 2008), or linked the adoption of such credits to the movement towards entrepreneurship for individuals working in companies impacted by the credit (Babina \& Howell, 2018). However, to date, there has been no paper that directly examines the overall impact of the R\&D tax credit on the rate, nature and scaling of new businesses.

At least in part, this gap in understanding arises from the fact that, among all new business starts, the nature of growth-oriented entrepreneurship is elusive. The vast majority of new firms are founded with the intention to remain small businesses (Hurst \& Pugsley, 2011). Only a very small fraction of startups experience the explosive growth (in terms of jobs, revenue, or valuation) that propels the economy and motivates economic development policy (Guzman \& Stern, 2016). And, at the time a company is founded, one cannot observe whether that particular firm will experience explosive growth (or not). Evaluating the effectiveness of fiscal incentives such as the state R\&D tax credit thus requires confronting a measurement quandary: How do we identify whether state $R \& D$ tax credits are generating the formation and accelerating the performance of the types of startups that have the potential for exponential growth (Fazio et al., 2016)?

We overcome this impasse by extending our earlier work (Guzman \& Stern, 2016) to leverage a novel dataset on tax incentives (Bartik, 2017). Building on the methodology of Guzman and Stern (2016), we combine business registration records and predictive analytics to leverage founding choices that signal growth intention and model the relationship of these choices to later growth outcomes. We use this mapping to prospectively account for differences in the growth potential (or quality) of startups at or near the time of founding and develop systematic measures of the quantity, quality-adjusted quantity, and scaling potential of entrepreneurship in a region (Guzman \& Stern, 2015, 2016, 2017). We then consider the respective interactions of those measures with the availability (or absence) of state-level $R \& D$ tax credits. 
More specifically, we combine data from the Startup Cartography project (SCP), tracking the quality, quantity, and performance of entrepreneurship, with data from the UpJohn Institute's Panel Database on Incentives and Taxes (PDIT) (Bartik, 2017), tracking the availability and effective rates of state-level tax incentives. Our resulting dataset includes entrepreneurship measures for all counties in 25 states from 1990 to 2010. Using a difference-in-differences approach at the county-level, with year, county and pre-trend fixed effects, our core analysis evaluates how changes in the R\&D tax credit impact the quantity, quality and performance of entrepreneurial activity. In addition, as an exercise to consider the impact of tax credits that are more distant from the incentives for innovation-driven entrepreneurship, we repeat our analysis examining the impact of state-level investment tax credits using a similar difference-indifferences framework.

We find striking evidence for the long-term impact of the introduction of state R\&D tax credits on the quantity and quality-adjusted quantity of entrepreneurship in a region. Accounting for county and year fixed effects, as well as lagged state GDP, we find that the introduction of state R\&D tax credits is associated with around 7\% increase in the rate of net new business formation (both in terms of raw quantity and accounting for the heterogeneous firm potential for growth). Moreover, this effect may underestimate the incentive's actual long-term impact. While state-level R\&D tax credits have little to no effect on the rate or composition of new firm formation in the first few years following their introduction, these incentives lead to a $20 \%$ increase in the quantity and quality-adjusted quantity of entrepreneurship over a ten year period (in the absence of any meaningful pre-adoption trend). Notably, these impacts stand in sharp contrast to the effects of other contemporaneous state fiscal incentives supporting established firms - state-level investment tax credits. ${ }^{2}$ For the investment tax credit, we see at best a neutral impact in terms of the overall quantity of entrepreneurship, and a longer-term decline in the quality-adjusted quantity of new firms founded, suggesting that, by enhancing the competitiveness of established businesses, the investment tax credit might serve to deter growthoriented entrepreneurship over time.

We conclude by observing that these results are informative for policy design. Though

\footnotetext{
${ }^{2}$ The PDIT panel centers on "incentives that are commonly used by medium to medium-large export-base firms" and excludes fiscal incentives geared towards incentivizing angel investment in pre-revenue startups.
} 
initially aimed at fostering innovation by established enterprises, state R\&D tax credits also increase the rate of entrepreneurship, and importantly, the formation of high growth potential startups needed to achieve economic development objectives. However, the R\&D tax credit does not offer a "quick fix" for states seeking to catalyze regional economic growth through entrepreneurship. Importantly, increases in the formation of high potential growth firms only materialize over time in response to $R \& D$ credits. Thus, it may take a decade or more for state R\&D tax credits to have an impact on the economy through entrepreneurship. More generally, tax incentives might be more effectively leveraged as one part of a broader complement of initiatives aimed at encouraging the formation and scaling of growth-oriented firms. Overall, our findings counsel in favor of "patient" and targeted policy-- offering longstanding tax incentives tailored towards the revenue trajectories of high-potential growth startups and encouraging investment in initiatives, including public-private partnerships, that support this important category of newly-founded firms.

\section{R\&D Tax Incentives And Regional Entrepreneurship: A Review Of The Evidence}

State R\&D tax credits and other types of fiscal incentives have proliferated since 1981, when their counterpart at the federal level was first introduced (Wilson, 2009). ${ }^{3}$ Between 1981 and 2006, 32 states introduced R\&D tax credits and the average effective credit rate grew fourfold (Wilson, 2009). Though originally adopted as an economic development tool to support existing firms already conducting R\&D (Miller \& Richard, 2010), many state governments expected R\&D tax credits would also help to advance their innovative capacity and industrial competitiveness either by creating or attracting new companies (Wu, 2008; Bartik \& Ebert,

\footnotetext{
${ }^{3}$ State-level investment tax credits have similarly proliferated over the past four decades, notwithstanding the repeal of the federal investment tax credit upon which they were modeled. As of 2004, $40 \%$ of states offered a general, statewide tax credit on investment in machinery and buildings with an average rate exceeding 6\% (Chirinko and Wilson, 2008 at Figure 1). Research finds positive impact from these incentives on investment (although of varying magnitude) (Bartik, 2018). We are not aware of research that considers the impact of general investment tax credits on entrepreneurial activity. However, in their evaluation of the federal investment tax credit prior to its repeal, Auerbach and Summers (1979) credited such incentives with "crowding out of non-favored investment" at a level sufficient "to offset a large percentage of the increase in the stock of equipment resulting from use of the credit." Accordingly, although likewise aimed at established firms, we would not expect state investment tax credits, as traditionally formulated, to have a positive impact on the creation of entrepreneurship. The effects of general investment tax credits on entrepreneurship thus offer a useful counterpart against which to compare similar analysis of the impact of state $R \& D$ tax credits.
} 
2011). Today, $R \& D$ tax credits have increasingly been positioned as a catalyst of startup activity - a mechanism to spur growth in the states' respective high-technology sectors by directly helping pre-revenue startups - above and beyond simply supporting established firms (Miller \& Richard, 2010).

However, in spite of the significant and growing state fiscal investment to foster entrepreneurship through $R \& D$ credits, the empirical evidence evaluating their impact is sparse. While an extensive literature investigates the impact of $R \& D$ tax credits on innovation, and another complementary literature considers how taxes broadly effect entry into entrepreneurship, there appears to be a lack of evidence on the question at the intersection of the two: how $R \& D$ fiscal incentives change the local production of entrepreneurship in those locations that adopt them. To the best of our knowledge, our paper is the first to empirically evaluate this important issue. ${ }^{4}$

To bridge this gap, we build on three related strands of economic literature that closely inform our area of study. First, there is a large and productive literature on the impact of R\&D tax credits on established firms. This work has established that such tax credits have a significant influence on R\&D investment as well as wider economic effects (Mansfield, 1986; Jaffe, 1986; Katz, 1986; Grossman \& Helpman, 1991; Hall \& Van Reenen, 2000; Bloom, Griffith, \& Van Reenen, 2002; Wilson, 2009; Wu 2005; Moretti \& Wilson, 2014; Branstetter \& Sakakibara, 2002; and Rao, 2013). ${ }^{5}$ Furthermore, at a macroeconomic level, R\&D tax credits appear to increase establishment-level dynamism among incumbent R\&D-performing firms (Lucking, 2019; Acemoglu et al., 2017).

Second, there is a body of literature considering how tax policy in general (rather than $R \& D$ fiscal incentives specifically) impacts entry into entrepreneurship. The findings of this

\footnotetext{
${ }^{4}$ The closest related paper is $\mathrm{Wu}$ (2008), who considers how the introduction of state R\&D credits changes the number of total active firms in the high technology sector. However, Wu's data does not allow him to actually separate between the entry and exit margin, or consider the varying quality of those firms that are marginally enticed to enter after the introduction of $R \& D$ credits.

${ }^{5}$ Drawn from Mukherjee, Abhiroop, Singh, Manpreet and Zaldokas, Alminas, "Do Corporate Taxes Hinder Innovation?", June 22, 2014 draft. See Hall and Van Reenen (2000) for a comprehensive survey on this topic. Because firms are known to relabel other costs as R\&D in an effort to claim tax credits (Griffith, 1996), it can be difficult to ascertain whether the R\&D spending response to tax changes reflects changes in productive innovative inputs as opposed to creative accounting. Recent research establishes that firms differ widely in the productivity of their R\&D investments (Hirshleifer, Hsu, \& Li, 2013) and these differences in innovative efficiency translate into differences in future sales (Cohen, Diether, \& Malloy, 2013).
} 
literature are mixed, and the effects often depend on the relative level of tax rates, structure of tax policy, risk tolerance of investors and the startups' stage of growth, though some general patterns do emerge. Generally speaking, entry into self-employment increases in response to lower marginal taxes (Bruce, 2000). Cuts in relative and across the board tax rates faced by entrepreneurs would likewise increase entrepreneurial entry (Gurley-Calvez \& Bruce, 2013). Conversely, higher marginal tax rates and a more convex tax system reduce entry into selfemployment for people who were previously employed in innovative industries and occupations (Gentry \& Hubbard, 2004). Progressive tax structures have countervailing effects for highincome agents, risk neutral investors on the one hand, and risk averse individuals, on the other. Since graduated rates tax gains more than subsidize losses, such rates discourage individuals from the former group from moving to the entrepreneurial sector and encourage it for the latter (Cullen \& Gordon, 2016). However, tax policy aimed at encouraging small business entry may come at the expense of discouraging later growth as preferential treatment is phased out and the government claims a larger share of payoffs for successful entrepreneurs (Holtz-Eakin, 1995; Gentry \& Hubbard, 2003). And, an across-the-board cut in tax rates would have a net positive impact on entrepreneurial spell length (Gurley-Calvez \& Bruce, 2007). ${ }^{6}$

Finally, third, there are a small number of papers that have touched more directly upon the topic of R\&D tax credits and entrepreneurship, even if not squarely looking at the impact of the former on the latter. Babina and Howell (2018) use changes in state and federal R\&D tax credits to study varying incentives to knowledge production in large firms and their spillovers into new startups, and Lokshin and Mohnen (2007) estimate the tax-price elasticity of R\&D spending in the Netherlands across firm sizes, finding larger elasticities for smaller firms and hypothesizing that the credit plays a major role in helping small firms increase R\&D expenditures in the face of more pressing capital constraints. The paper that is closest to ours is Wu (2008), which links state R\&D tax credits to the growth of the high tech sector. Wu (2008) finds that state $R \& D$ tax credits have significant and positive impacts on the number of active high-technology establishments and as a share of business establishments overall within states. However, $\mathrm{Wu}(2008)$ leaves open the question as to whether any temporal rise observed reflects

\footnotetext{
${ }^{6}$ Drawn from Gale and Brown's (2013) survey of the literature considering how federal tax policy affects small business.
} 
an increase in entrepreneurship, survival, or other aspects. In conclusion, while much research has been done in adjacent areas, the empirical evidence on the impact of R\&D tax credits on entrepreneurship continues to be largely missing.

Studying this question presents not only challenges in systematic empirical analysis, but also the need to solve fundamental data issues at the core of entrepreneurship measurement. As emphasized in Guzman and Stern (2017), ecosystem entrepreneurship cannot simply be summarized by the count of new firms, but instead represents three distinct margins, each varying independently across locations: the regional quantity, representing the number of firms being created in a location; the regional quality, representing the heterogeneous underlying potential of firms at founding and their regional distribution; and ecosystem effects, representing the better or worse performance across locations for startups founded with the same quality. State R\&D tax credits could impact entrepreneurship across any one of these margins, or all of them, potentially even with each moving in different directions. Without accounting systematically for each of these effects, the net-impact of state R\&D tax credits on entrepreneurship (from the policy maker's perspective) cannot be assessed.

Therefore, developing an approach to create systematic regional measures of the quantity of entrepreneurship, its quality, and the ecosystem performance, in a way that can be done comprehensively across the United States (or another large geography) is a central and necessary requirement to careful study. This is the question to which we now turn.

\section{Empirical Framework}

We now proceed to describe our empirical framework. To do so, we build on our earlier work using business registration records and predictive analytics to measure the quality and quantity of entrepreneurship across regions (Guzman \& Stern, 2015, 2016, 2017; Fazio et al., 2017). Then, we use these regional measures to setup a difference-in-differences empirical specification that takes advantage of the staggered introduction of tax credits to measure their impact on regional entrepreneurship outcomes. We review each below. 


\section{A. Measuring Regional Entrepreneurship: An Entrepreneurial Quality Approach. ${ }^{7}$}

Our entrepreneurship measurement approach builds from Guzman and Stern (2016), where we develop a way to measure the founding quality of startups using predictive analytics and business registration records. Our approach combines three interrelated insights. First, as the challenges to reach a growth outcome as a sole proprietorship are formidable, a practical requirement for any entrepreneur to achieve growth is business registration (as a corporation, partnership, or limited liability company). This practical requirement allows us to form a population sample of entrepreneurs "at risk" of growth at a similar (and foundational) stage of the entrepreneurial process. Second, we are able to potentially distinguish among business registrants through the measurement of founding choices observable at or close to the time of registration. For example, we can measure start-up characteristics (which result from the initial entrepreneurial choices in our model) such as whether the founders name the firm after themselves (eponymy), whether the firm is organized in order to facilitate equity financing (e.g., registering as a corporation or in Delaware), or whether the firm seeks intellectual property protection (e.g., a patent or trademark). Third, though rare, we observe meaningful growth outcomes (such as achieving an IPO or high-value acquisition) for some firms. Combining these insights, we estimate entrepreneurial quality by estimating the relationship between observed growth outcomes and start-up characteristics.

That is, for a firm $i$ born in region $r$ at time $t$, with at-birth start-up characteristics $K_{i, r, t}$, we observe growth outcome $g_{i, r, t+s} s$ years after founding and estimate:

$$
\theta_{i, r, t}=P\left(g_{i, r, t+s} \mid K_{i, r, t}\right)=f\left(\alpha+\beta K_{i, r, t}\right)
$$

And use the predicted value of this regression as our measure of entrepreneurial quality.

As long as the process by which start-up characteristics map to growth remain stable over time (an assumption which is itself testable), this mapping allows us to form an estimate of founding characteristics to entrepreneurial quality for any business registrant within our sample.

We use these estimates to generate three entrepreneurship statistics capturing the level of

\footnotetext{
${ }^{7}$ This section draws heavily (if not verbatim) from our prior work in Guzman and Stern (2016; 2017), where we originally introduce these measurement statistics.
} 
entrepreneurial quality for a given population of start-ups, the potential for growth entrepreneurship within a given region and start-up cohort, and the performance over time of a regional entrepreneurial ecosystem in realizing the potential performance of firms founded within a given location and time period.

The Entrepreneurial Quality Index (EQI). To create an index of entrepreneurial quality for any group of firms (e.g., all the firms within a particular cohort or a group of firms satisfying a particular condition), we simply take the average quality within that group. Specifically, in our regional analysis, we define the Entrepreneurial Quality Index (EQI) as an aggregate of quality at the region-year level by simply estimating the average of $\theta_{i, r, t}$ over that region:

$$
E Q I_{r, t}=\frac{1}{N_{r, t}} \sum_{i \in\left\{I_{r, t}\right\}} \theta_{i, r, t}
$$

where $\left\{I_{r, t}\right\}$ represents the set of all firms in region $r$ and year $t$, and $N_{r, t}$ represents the number of firms in that region-year. To ensure that our estimate of entrepreneurial quality for region $r$ reflects the quality of start-ups in that location rather than simply assuming that start-ups from a given location are associated with a given level of quality, we exclude any location-specific measures from the vector of observable start-up characteristics.

The Regional Entrepreneurship Cohort Potential Index (RECPI). From the perspective of a given region, the overall inherent potential for a cohort of start-ups combines both the quality of entrepreneurship in a region and the number of firms in such region (a measure of quantity). To do so, we define RECPI as simply EQI multiplied by the number of firms in that region-year:

$$
\mathrm{RECPI}_{\mathrm{r}, \mathrm{t}}=\mathrm{EQI}_{\mathrm{r}, \mathrm{t}} \times \mathrm{N}_{\mathrm{r}, \mathrm{t}}
$$

Since our index multiplies the average probability of a firm in a region-year to achieve growth (quality) by the number of firms, it is, by definition, the expected number of growth events from a region-year given the start-up characteristics of a cohort at birth. This measure of course abstracts away from the ability of a region to realize the performance of start-ups founded within a given cohort (i.e., its ecosystem performance), and instead can be interpreted as a measure of the "potential" of a region given the "intrinsic" quality of firms at birth, which can then be affected by the impact of the entrepreneurial ecosystem, or shocks to the economy and the cohort 
between the time of founding and a growth outcome.

The Regional Ecosystem Acceleration Index (REAI). While RECPI estimates the expected number of growth events for a given group of firms, over time we can observe the realized number of growth events from that cohort. This difference can be interpreted as the relative ability of firms within a given region to grow, conditional on their initial entrepreneurial quality. Variation in ecosystem performance could result from differences across regional ecosystems in their ability to nurture the growth of start-up firms, or changes over time due to financing cycles or economic conditions. We define REAI as the ratio of realized growth events to expected growth events:

$$
R E A I_{r, t}=\frac{\# \text { of growth event } s_{r, t}}{R E C P I_{r, t}}
$$

A value of REAI above one indicates a region-cohort that realizes a greater than expected number of growth events (and a value below one indicates under-performance relative to expectations). REAI is a measure of a regional performance premium: the rate at which the regional business ecosystem supports high potential firms in the process of becoming growth firms.

Together, EQI, RECPI, and REAI offer researchers and regional stakeholders the ability to undertake detailed evaluations (over time, and at different levels of geographic and sectorial granularity) of entrepreneurial quality and ecosystem performance.

\section{B. Empirical Specification.}

Building on this setup, we take advantage of the staggered introduction of tax incentives across different states in the United States to measure the difference in the average creation of local entrepreneurship for counties that have a tax incentive versus those that do not. Specifically, for a measure of entrepreneurship $Y_{r, t}$, estimated in county $r$ at time $t$, we estimate the specification

$$
Y_{r, t}=\alpha+\gamma_{r}+\lambda_{t}+\beta D_{r, t}+\epsilon_{r, t}
$$

where $D_{i, t}$ is an indicator variable equal to 1 if a tax incentive has been included and 0 otherwise, $\gamma_{r}$ are individual county level fixed effects, $\lambda_{t}$ are year fixed effects, and $\epsilon_{r, t}$ is an error term. 
The coefficient of interest is $\beta$, which estimates the average change in entrepreneurship (either RECPI, quality, or quantity) with and without the tax incentive. After controlling for mean levels of county and year effects, the key identifying assumption is lack of correlation between the imposition of the policy and the trend in county-level entrepreneurship (which is itself testable).

One common concern in difference-in-differences implementations for policy evaluation, like our case, is the existence of pre-trends. Specifically, the concern is that for some unmeasured reason counties that are already in an upward or downward trend in entrepreneurship levels are also more likely to have R\&D tax credits. For example, more urban settings can be more conducive to R\&D policies and have more startups, so that localized changes in urbanization, rather than the availability of $R \& D$ tax credits, can be driving measured differences in entrepreneurship between those counties that have the credit and those that do not. If these unobserved factors exist and are not fully controlled for, then the observed impact of the $\mathrm{R} \& \mathrm{D}$ tax credit will be biased. We test for the existence of pre-trends in several ways, such as by running models that estimate pre-trends, by including additional controls that are most likely to be correlated with these pre-trends (e.g., regional GDP), and by plotting individual coefficients for each lag / lead to the tax incentive.

Finally, a second concern is that the standard errors are biased downward when there exists correlation in the unobserved component across different observations in the same county (and which therefore are exposed to the same tax incentive), or between different counties in the same year. To account for these concerns, we use the multi-way clustering approach (Cameron et al., 2011) and cluster our standard errors by both county and year. 


\section{Data}

To implement the empirical framework described in Section III, we need to combine systematic measures of the quantity and quality of regional entrepreneurship with measures of tax policy and other control variables over time. We construct a dataset including county-level measures of entrepreneurship from the Startup Cartography Project with measures of business tax credits from the Panel Database on Incentives and Taxes. We therefore review each of these data sources in turn

\section{A. The Startup Cartography Project Dataset ${ }^{8}$}

The underlying dataset consists of all new business registrations across 34 US states (representing more than $80 \%$ of US GDP) from 1988 through 2012 that satisfy one of the following conditions: (a) a for-profit firm in the local jurisdiction or (b) a for-profit firm whose jurisdiction is Delaware but whose principal office address is in the local state. Our analysis excludes non-profit organizations as well as companies whose primary location is not in the state. The resulting dataset contains $18,916,895$ observations.

For each observation we construct variables related to: (i) growth outcomes (IPO or significant acquisition); (ii) firm characteristics based on business registration observables; and (iii) firm characteristics based on external data that can be directly linked to the firm (e.g. patents, trademarks).

i. Growth Outcomes. The growth outcome, Growth, is a dummy variable equal to 1 if the firm has an initial public offering (IPO) or is acquired at a meaningful positive valuation within 6 years of registration as reported in the Thomson Reuters SDC database. ${ }^{9}$

\footnotetext{
${ }^{8}$ This section draws heavily from this prior work in Guzman and Stern (2016), where we introduce business registration records and many of the measures used in this paper.

${ }^{9}$ Although the coverage of IPOs is likely to be nearly comprehensive, the SDC data set excludes some acquisitions. SDC captures their list of acquisitions by using over 200 news sources, SEC filings, trade publications, wires, and proprietary sources of investment banks, law firms, and other advisors (Churchwell, 2016). Barnes, Harp, and Oler (2014) compare the quality of the SDC data to acquisitions by public firms and find a 95\% accuracy (Nette, Stegemoller, and Wintoki (2011), also perform a similar review). While we know this data not to be perfect, we believe it to have relatively good coverage of 'high value' acquisitions. We also note that none of the cited studies found significant false positives, suggesting that the only effect of the acquisitions we do not track will be an
} 
ii. Firm Characteristic Measures Based on Business Registration Data. We first create two binary measures that relate to how the firm is registered:

Corporation, which captures whether the firm is a corporation rather than an LLC or partnership, and Delaware, equal to one if the firm is registered in Delaware. We then create five additional measures based directly on the name of the firm. Eponymous is equal to 1 if the first, middle, or last name of the top managers is part of the name of the firm itself. ${ }^{10}$ Our last measure relates to the structure of the firm name. Based on our review of naming patterns of growth-oriented startups versus the full business registration database, a striking feature of growth-oriented firms is that the vast majority of their names are at most two words (plus perhaps one additional word to capture the organizational form, e.g. "Inc."). We define Short Name to be equal to one if the entire firm name has three or less words, and zero otherwise. ${ }^{11}$ We then create several measures based on how the firm name reflects the industry or sector within which the firm is operating, taking advantage of the industry categorization of the US Cluster Mapping Project ("US CMP”) (Delgado, Porter, and Stern, 2016) and a text analysis approach. We develop seven such measures. The first three are associated with broad industry sectors and include whether a firm can be identified as local (Local), traded (Traded) or resource intensive (Resource Intensive). The other five industry groups are narrowly defined high technology sectors that are typically associated with high growth firms, including whether the firm is within the biotech (Biotech Sector), e-commerce (E-Commerce), other information technology (IT), medical devices (Medical Devices) or semiconductors (Semiconductor) space.

\footnotetext{
attenuation of our estimated coefficients.

${ }^{10}$ Belenzon, Chatterji, and Daley (2017a, 2017b) perform a more detailed analysis of the interaction between eponymy and firm performance finding an important negative relationship between an intent to use equity financing and eponymy.

${ }^{11}$ Companies such as Akamai or Biogen have sharp and distinctive names, whereas more traditional businesses often have long and descriptive names (e.g., "New England Commercial Realty Advisors, Inc.”).
} 
iii. Firm Characteristic Measures Based on External Observables. We also construct two measures related to quality based on data from the U.S. Patent and Trademark Office. Patent is equal to 1 if a firm holds a patent application within the first year and 0 otherwise. We include patents that are filed by the firm within the first year of registration and patents that are assigned to the firm within the first year from another entity (e.g., an inventor or another firm). Our second measure, Trademark, is equal to 1 if a firm applies for trademark protection within a year from registration.

Entrepreneurial Quality Logit Model. We use this data to estimate a logit regression model that allows one to examine how the presence or absence of a startup characteristic correlates with the probability of growth (conditioning on the presence or absence of other startup characteristics). Table 1 reports our results for all startups between 1988 and 2006. The results are striking. We find an extremely strong (and robust) correlation between startup characteristics and the probability of growth. Substantial changes in the predicted likelihood of a growth outcome are associated with characteristics observable in real time from business registration records as well as characteristics observable with a lag (e.g., patent and trademark applications). On the one hand, startups founded as corporations are almost 390\% more likely to grow. Similarly, firms with short names, and those using biotech industry descriptors, are (respectively) close to $90 \%$ and $130 \%$ more likely to grow. On the other, eponymous firms and those with local industry descriptors are $74 \%$ and $57 \%$ less likely to grow, respectively. Finally, these changes in predicted probabilities are multiplicative in nature: a startup that registers in Delaware and applies for a patent in its first year is 210 times more likely to grow than a firm that only registers in its home state and does not apply for intellectual property protection. ${ }^{12}$

\section{Quantitative Estimates Of Entrepreneurial Quantity And Quality-Adjusted Quantity.}

These findings can be used to construct, for every registered firm in the dataset, its underlying probability of growth at founding. The probability of growth for an average firm is very low (on the order of one in 3,500). However, for those firms with multiple startup characteristics that

\footnotetext{
${ }^{12}$ It is very important to emphasize that these startup characteristics are not the causal drivers of growth, but instead are "digital signatures" that allow us to distinguish firms in terms of their entrepreneurial quality. Registering in Delaware or filing for a patent will not guarantee a growth outcome for a new business, but the firms that historically have engaged in those activities have been associated with skewed growth outcomes
} 
positively predict growth, the probability of growth is dramatically higher (the top 1 percent of firms have a better than one in 100 chance of achieving growth outcomes). These estimates of entrepreneurial quality at the firm level can, in turn, be used to develop economic indices that simultaneously account for both the quantity and the quality of entrepreneurship (and which are outlined in the empirical framework section):

- EQI - the Entrepreneurial Quality Index - the average growth potential (or "quality") of any given group of new firms.

- RECPI - the Regional Entrepreneurship Cohort Potential Index - the number of startups within a particular location or region expected to later achieve a significant growth outcome.

- REAI - the Regional Entrepreneurship Acceleration Index — the ability of a region to convert entrepreneurial potential into realized growth.

Each index calculates a different quantitative measure that incorporates the quality of entrepreneurship. The EQI, RECPI, and REAI indexes give a better indication than possible under traditional methods about just how skewed the distributions of growth potential and likely growth outcomes are (and whether and to what extent a greater number of small to medium-sized businesses could be expected to catalyze the same growth outcomes as a high-potential growth firm). ${ }^{13}$ Additionally, REAI systematically quantifies the ratio of realized to expected growth events for a given cohort of new firms, providing an indication of whether the ecosystem in which a cohort of new firms is located is conducive to growth (or not). As such, these indexes offer policymakers and stakeholders a better view of whether and to what extent their regions are attracting/generating startups with high-growth potential vs. helping/hampering these firms' efforts to realize their potential.

\footnotetext{
${ }^{13}$ The level of skewness of entrepreneurial quality is highly informative. It indicates how much more likely a startup at the high end of the entrepreneurial quality distribution is to grow than an average firm. If skewness were low, then adding several average firms could have as much regional impact as one high-growth-potential firm. But, if skewness is high (as the findings indicate), then a much larger number of firms with average growth potential is needed to generate the expected impact of one high-potential firm. Given the level of skewness observed, almost 4,000 local limited liability companies (average firm) are needed to generate the same potential as only one new Delaware corporation with an early patent and trademark. Put another way, initial ambition/potential for growth is a key dimension of heterogeneity across new firms. The subset of high-potential-growth startups is very small and fundamentally different than the vast majority of new firms
} 
Aggregating Across Locations. Finally, we aggregate our estimates for all firms in our sample. To do so, we use the registered ZIP Code of each company to identify each county using the HUD USPS ZIP Code crosswalk files. We then aggregate across each county and year to estimate quality, quantity, RECPI and REAI based on the observed outcomes in each one. Our resulting dataset is made publicly available in the Startup Cartography Project website.

\section{B. Measuring R\&D tax credits: The Panel Database on Incentives and Taxes ${ }^{14}$}

To incorporate the incidence and existence of R\&D and investment tax credits into our study, we take advantage of a new dataset, The Panel Database on Incentives and Taxes (PDIT), created by Bartik (2017). The PDIT estimates, from 1990 to 2015, marginal taxes and business incentives for an average firm in each of 47 cities in 33 states (reported in Figure 1B), and 45 industries over 26 years. It simulates average taxes and incentives by considering the following scenario: a business in some industry $i$ creates a new branch facility. That new facility is set up in some particular city $c$, in some state $s$, and starts operation in some year $t$. Taxes and incentives for the new facility are projected for the facility's first 20 years of operation, and the facility is assumed to operate at the same scale during that time. ${ }^{15}$ To calculate state and local taxes for this new facility, data based on industry averages are used for the firm's balance sheet (including for value-added, pretax profits, mix of property assets, employment, wages, and R\&D spending). From this balance sheet information, and from information on state and local business tax rates, and information on rules for how incentives are determined based on firm characteristics, state and local taxes and incentives are calculated for each year of the assumed 20 years of operation of the new facility. The present value of the 20-year stream of such taxes and incentives is calculated using a discount rate of $12 \%$.

The database thus describes how business incentives vary over the term of a new business investment (from year 1 to year 20), and it breaks down incentives into different types, including

\footnotetext{
${ }^{14}$ This section draws heavily (if not verbatim) from Bartik, 2017.

${ }^{15}$ In assigning taxes and incentives to this new facility over the 20 years, the same incentive and tax rules in place for year $t$ are assumed to remain unchanged through year $t+20$. This assumption can be seen as taking the perspective of a business that myopically projects current tax and incentive rules into the future. (When taxes and incentives are calculated for the same city and state in some future year $\mathrm{t} 1$, the tax rules and incentives for year $\mathrm{t} 1$ are carried forward for 20 years.)
} 
investment tax credits (ITCs) and research and development (R\&D) tax credits. ${ }^{16,17}$ It allows these incentives to be subjected to descriptive analyses, including an examination of time trends in different types of incentives, and analysis of how incentives vary with a state's economic prosperity or with an industry's wage rates.

\section{Descriptive Statistics.}

Our dataset merges the Startup Cartography Project data with the PDIT, creating a complete panel of 25 overlapping US states from 1990 to 2010 with 30,093 and 5 variables. Table 1 reports summary statistics. Obs, represents the count of individual registrations in each county-year. There are 397 new business registrants on average in a county and year. However, the distribution is highly skewed, with a standard deviation of 1,948. RECPI, represents our headline index, the quality-adjusted quantity of entrepreneurship. It indicates the expected number of growth events given the founding characteristics of new businesses in a specific county and year. The mean is 0.37 with a standard deviation of 2 . REAI, indicates the ecosystem performance index, which is the ratio of realized growth events versus predicted growth ones. The mean 0.64 with a standard deviation of 6 .

We create two measures from the PDIT reflecting the presence or absence of the indicated tax credits in the states in question. Has $R \& D$ Tax Credit is a binary variable equal to 1 if the county has an R\&D tax credit during that year and zero otherwise. $46 \%$ of the countyyear observations have an R\&D tax credit, allowing well-balanced variation in our data. To avoid issues particular to the transitioning year when the tax credit is introduced, we drop all county-years observations when the tax credit is introduced $(\mathrm{N}=869)$, therefore simply observing the time before and after the credit. Has Investment Credit is a binary variable equal

\footnotetext{
${ }^{16}$ The PDIT does not include all tax incentives offered across all states. Instead, it centers on "incentives that are commonly used by medium to medium-large export-base firms. The goal of the PDIT is to measure the "standard deal" that would be offered to a medium-sized export-base new facility that the state and city wished to attract. These incentives may not be offered to all firms, but they are commonly offered to many firms." As such, Investment tax credits targeted at specific sectors (such as the biotechnology sector) or startup firms (such as angel investment tax credits) are not included in the PDIT panel.

${ }^{17}$ We distinguish general state investment tax credits from ones targeted towards encouraging early stage capital investment (which are not included in the Panel Database on Incentives and Taxes (PDIT) (Bartik, 2017) and therefore not the subject of our analysis). Bell et al. (2013) finds that more than 30 states offered targeted angel investment tax credits as of 2012 and that these incentives were correlated positively with an increase in the quantity of state-level entrepreneurial activity within two years after introduction.
} 
to 1 if the county has an investment credit during the year of the observation and zero otherwise. $38 \%$ of the observations in our sample have an investment credit. We drop the 721 observations representing county-year observations in which the credit is introduced.

\section{Empirical Results}

We now proceed to estimate the impact of $R \& D$ tax credits on the level of regional entrepreneurship through our difference-in-differences approach. In Table 3, we report the difference in the quantity of newly founded companies (Obs), the difference in the qualityadjusted quantity of companies (RECPI) and difference on the performance of companies conditional on being founded ( $R E A I)$, for those counties that have an $\mathrm{R} \& \mathrm{D}$ tax credit versus those that do not. For Obs and RECPI, we use the logarithm as our dependent variables to control for skewness in the variables and to allow easier interpretation of our estimates as elasticities. However, we do not $\log R E A I$ as it is already a ratio that can be directly interpreted. Standard errors are clustered two-ways by year of observation and county to account for correlation in the error terms across either of those dimensions.

Model 1 is a naïve model without any controls. It reports the cross-sectional differences in the levels of entrepreneurship between locations that have R\&D tax credits and those that do not. In a way, they represent the perceived differences in entrepreneurship for the casual policy observer, or for those who might be doing a comparative analysis between regions at a point in time. We observe substantially more entrepreneurship in counties with R\&D credits than without. Column (1) indicates that counties with R\&D credits have $48 \%$ higher total quantity of firms. Column (2) indicates that they have 64\% higher total quality-adjusted quantity of firms. Interestingly, column (3) shows a negative relationship between REAI and the R\&D credit. Firms in counties with R\&D credits are $14 \%$ less likely to achieve growth outcomes compared to firms in counties that do not have the credit.

Of course, cross-sectional differences like those of Model 1 are likely to suffer from significant omitted variable bias. For example, it is likely that locations that are more urban simply have more economic development support (which will include tax credits) and more firms, so that R\&D credits and entrepreneurship will be positively correlated due to the omitted 
variable of urbanization. As well, variation in the business cycle would also influence the founding and quality of new companies and policy introductions. Unless the business cycle is accounted for, the estimates will be similarly biased.

Model II is our preferred difference-in-differences estimate. In Model II, we control for constant differences across counties by including county fixed-effects and for the business cycle effects and other national shocks by including year fixed-effects. If the choice to introduce an R\&D tax credit in any state is random after controlling for these two sources of endogeneity, then our estimate is identified.

Highlighting the important role of omitted variables in determining which counties eventually offer R\&D credits, our estimates decrease significantly from the naïve model to the differences in differences model. Column (1) reports an average difference in the quantity of entrepreneurship of $7.5 \%$ between counties with R\&D credits compared to those without, conditional on the fixed-effects. Column (2) reports a difference of $7.6 \%$ for the quality adjusted quantity of entrepreneurship. Finally, in Column (3) we report our estimate of the effect of R\&D tax credits on the ecosystem performance, which is now equivalent to zero. These results emphasize a meaningful main effect of R\&D tax credits on the rate of entrepreneurship for counties in our sample. Notably, the introduction of R\&D tax credits increases the rate of entrepreneurship, but changes neither its composition nor its acceleration. Both the quantity and the quality adjusted quantity of entrepreneurship increase in equal proportion. While counties with an R\&D tax credit enjoy an increase in the rate of business formation, that increase reflects the same mix of entrepreneurial quality previously found in the region. Moreover, counties with an R\&D credit are no more effective at helping startups to realize growth outcomes (relative to initial quality) than those without. While lowering the capital cost of R\&D leads to more employee departures for entrepreneurship (Babina \& Howell, 2018), beyond potential knowledge spillovers, it does not appear to have broader ecosystem effects.

Robustness Tests. We now consider the potential threats to the validity of our estimate. As in most difference in differences panel models, the main threat to validity is the potential role of pre-trends in our treated counties. While we control for fixed characteristics of counties and time periods, there can potentially be region-specific omitted variables that drive both entrepreneurship levels and the introduction of $R \& D$ tax credits, making our results artificially 
higher. For example, localized economic and population growth would increase the level of entrepreneurship in a region and might lead to legislative choices such as the introduction of tax credits. Conversely, however, the process of policymaking is often driven by state-level elements of politics that are more random, and might be uncorrelated with trends of entrepreneurship. In Models III and IV, we evaluate some potential threats to validity in our estimates by considering two obvious potential confounders, pre-trends and the state economy.

In Model III, we control for county pre-trends by estimating the predicted value of entrepreneurship for each county if it had not implemented the R\&D tax credit. Specifically, for all counties, we estimate a county specific trend coefficient using only the observations where Has $R \& D$ Credit is zero, then predict the level of entrepreneurship (either quantity, qualityadjusted quantity, or ecosystem effects) on all observations based on this trend. We include these predicted values as individual county trends for all observations. The point estimates of the impact of R\&D tax credits are close to those of Model II (in fact, slightly higher) and the differences are not statistically significant.

In Model IV, we control directly for the most obvious potential bias in the policy-making process of state legislatures, the state-specific economy, by including the state GDP as a control directly in our regression. Once again, the point estimates are quite close to those of Model II, and the differences are not statistically significant.

We move to a graphical analysis of pre-trends in Figure 2, where we report the yearspecific trends in the five years preceding the introduction of the R\&D tax credit. To do so, we estimate regressions with time-specific coefficients in the years before and after the introduction of the R\&D tax credit. Consistent with our other results, we do not observe any pre-trends in either the quantity or the quality-adjusted quantity of entrepreneurship.

Together, our results provide compelling evidence of a lack of pre-trends in the introduction of state R\&D tax credits. This evidence suggests the threats to validity do not hold in our estimates and, therefore, they can be interpreted as causal.

The Impact of State $R \& D$ Tax Credits Through Time. While we have observed a mean difference in the effect of state $R \& D$ tax credits on regional entrepreneurship, there is reason to believe that this effect would vary over time. In particular, we expect R\&D tax credits to have 
long-term effects on a local startup ecosystem. For example, the credit might change not only the marginal cost of starting a company for those ideas already existing, but also the supply of new ideas themselves as entrepreneurs and investors are motivated by the expectation of lower capital costs, thus leading to longer-term effects on regional entrepreneurship.

We study this possibility in Model V of Table 3. To do so, we change our core difference-in-differences specification in Model II to include time-varying effects through two variables. The first variable, Years Before Credit, is equal to the (negative) number of years prior to the tax credit's introduction, and zero when the tax credit has been introduced. Its coefficient indicates the presence of pre-trends in the data. The second variable Years After Credit, is equal to the number of years after the tax credit is introduced, and zero when it has not been included. We also include a level effect of R\&D tax credit by keeping our main variable Has $R \& D$ Credit. Our estimates show no pre-trends, highlighting once again that there is no conditional endogeneity in the introduction of the tax credit. We also show no effect on the main variable. However, we see a positive and significant coefficient of 0.023 of our time trend on the level of entrepreneurship for both quantity and quality-adjusted quantity. These estimates suggest that there is not an initial increase in entrepreneurship immediately following the introduction of a tax credit. However, there is a subsequent improvement of $2 \%$ per year for every year the credit has been active.

We revisit these estimates with yearly coefficients after treatment in Figure 2, and observe the same increasing pattern. There is no increase in the level of entrepreneurship immediately following the introduction of the R\&D tax credit. However, there is an upward trend that begins after year 3 and continues up to year 14. Consistent with our average increase of $2 \%$ per year in our regressions, we see a difference of about $20 \%$ in the level of entrepreneurship by year 10 .

Together, our results provide evidence showing that there is a significant effect of state R\&D tax credits on the rate of entrepreneurship, but that this effect only accumulates through time. Counties should expect to wait a few years following the introduction of a credit to see any initial effects and up to a decade to see effects that are substantial. 


\section{Investment Tax Credits}

As an additional exercise, we repeat our analysis studying the impact of a different type of tax credit, the investment tax credit, on entrepreneurship. Table 4 repeats our estimates using the variable Has Investment Tax Credit as the independent variable. The regressions are otherwise the same.

Model I reports the naïve model, representing the cross-section correlation that would be observed by simply comparing the levels of entrepreneurship between those counties that have investment tax credits and those that do not. As is the case with $R \& D$ tax credits, the correlation is positive and substantial. Counties with investment tax credits have $71 \%$ higher quantity of entrepreneurship and 35\% higher quality-adjusted quantity.

The relationship changes in Model II, where we introduce county and year fixed effects. The relationship to entrepreneurship is now negative. Investment tax credits are associated with a decrease of $5 \%$ in the quantity of entrepreneurship, though not statistically significant, and a decrease of $9 \%$ in the quality-adjusted quantity, which is statistically significant. This is in sharp contrast to R\&D tax credits, which showed a positive relationship to regional entrepreneurship.

Models III and IV perform robustness tests on our data by including county pre-trends (as explained for Table 3) and state level GDP. The results are mostly unchanged. The coefficients are close to the baseline estimate of Model II and are not statistically different from them. Figure 3 also shows the pre-trends for the five years prior to the introduction of the credit. While

slightly noisier than the R\&D credits, we do not observe any pre-trends on the process to introducing investment tax credits.

Model V considers the time-specific impact of investment tax credits on entrepreneurship. Our estimates indicate that there is no main effect from investment tax credits on the level of entrepreneurship, but that there is a negative trend which is significant. For each year that the investment tax credit is active, there is a decrease of $0.7 \%$ in the quantity, and $1.1 \%$ in the quality-adjusted quantity of entrepreneurship.

We look at these effects in more detail in Figure 3, which reports time-specific level coefficients for each outcome. There is a negative trend in the quantity of companies following the credit, but the pattern appears quite noisy. It is more precise when considering the quality- 
adjusted quantity of entrepreneurship, where there is a negative trend that becomes more significant through time.

Generally, we conclude the effects of the investment tax credit are negative on entrepreneurship, and more specifically high growth potential firms, suggesting a 'crowding out' effect on investment in the region as the investment tax credit is taken advantage of by large companies. This stands in sharp contrast to the positive effects we identified for R\&D credits, painting a nuanced picture of the role of tax incentives on entrepreneurship and its subsequent development, with both positive and negative effects being possible.

\section{Conclusion}

Innovation and entrepreneurship are central to economic growth and an increasing focus of state-level economic development policy. States are offering R\&D tax credits to both encourage innovation and support high-technology clusters within regions. With the locus of innovation shifting to startups in high-tech industries, and the majority of net new job creation resulting from the expansion of young high-potential growth firms (Haltiwanger et al., 2013; Guzman \& Stern 2016), state-level R\&D tax credits must create high growth entrepreneurship (either directly or via spillovers) to be an effective tool for economic development.

R\&D tax credits appear particularly well suited for the creation of endogenous highgrowth entrepreneurship in a region. These incentives lower the cost of capital and the incremental expense of research, encouraging investment in innovation and generating spillovers strengthening high-technology sectors within regions (Wu, 2008). Historically, such tax credits were designed for and used by established industries, leaving open the question of whether and to what extent R\&D tax credits generate the type of entrepreneurship needed for economic growth and/or greater realization of growth outcomes. Our findings on state R\&D tax credits offer a new lens through which to understand the impact of these fiscal incentives on both the rate of entrepreneurship and its composition, as well as the time it takes for effects to emerge. Our results on investment tax credits present an interesting counterpart against which the impacts of R\&D tax credits may be compared and understood.

While $\mathrm{R} \& \mathrm{D}$ tax credits increase the quantity and the quality-adjusted quantity of new 
firms founded in equal proportion, investment tax credits change the mix of new firm formation, decreasing the rate of high-growth potential entrepreneurship credited with the majority of new job creation. The causal impact of R\&D and investment tax credits on entrepreneurship take time to emerge and build over time. Over the long term, R\&D tax credits empower regions to significantly increase both the quantity of entrepreneurship and number of expected growth outcomes. Counties with $R \& D$ tax credits experience a rise in the rate of new firm formation and the number of expected growth outcomes by $2 \%$ per year and $20 \%$ over a ten-year period. Similarly, the negative impacts of investment tax credits on the quality-adjusted quantity of entrepreneurship build over time, decreasing the incidence of expected growth outcomes by $1.2 \%$ per year and $12 \%$ in total over a ten-year period. Last, but not least, our findings dampen expectations of achieving an indirect ecosystem effect, showing no causal relationship between the introduction of credits and later startup performance.

Our findings have important implications for policy design. First, and not surprisingly, the impact of tax incentives on entrepreneurship and its subsequent development is neither uniform nor unidirectional. Both positive and negative effects are possible. R\&D tax credits generate the form of entrepreneurship needed for economic growth, while investment tax credits retard it. States offering both $R \& D$ and investment tax credits in an effort to stimulate highgrowth entrepreneurship may be offering incentives that work at cross purposes.

Second, the differential impact of R\&D and investment tax credits on the composition of entrepreneurial entry - i.e., the rate of formation of main-street vs. high growth potential startups -- suggests that the structure of such incentives matters to later outcomes. While R\&D tax credits do generate substantial increases in the quantity and quality-adjusted quantity of new firms founded, they do not change the mix of main-street and innovation driven firms. Investment tax credits offered to established firms appear to crowd out the formation of new high-growth potential startups. Our findings do not foreclose the possibility, however, that more targeted investment tax credits, such as those specifically tailored towards supporting the biotech industry or angel investment, could have the opposite effect. ${ }^{18}$ Our findings leave open the

\footnotetext{
${ }^{18}$ Bell et al. (2013), for example, find an increase in the quantity of entrepreneurship in the two years following the implementation of an angel investment tax credit. Further research is needed to study the impact of more tailored investment tax credits on the composition of new firm formation and, more specifically, the quality adjusted quality of entrepreneurship. Similarly, consideration of whether and to what extent the level of R\&D credit offered and its
} 
prospect that policy experimentation with the intensity and terms of these fiscal incentives could identify structures that better amplify the type of entrepreneurship most needed for later economic growth.

Third, R\&D tax credits offer no universal salve for accelerating entrepreneurial ecosystems. R\&D tax credits do generate meaningful increases in the formation rates of growthoriented startups. Indeed, recent research confirms labor reallocation as one important mechanism through which this effect occurs (Babina \& Howell, 2018). However, counties with R\&D credits are no more effective at helping startups to realize growth outcomes than those without. Thus, while R\&D tax credits will lead to creation of more growth-oriented startups, policymakers cannot also count on R\&D tax credits to improve those startup's performance. Policymakers should consider complementing R\&D tax credits with other programs and initiatives to support startups as they scale.

Finally, our findings suggest a time horizon over which policy impact from R\&D and investment tax incentives may reasonably be expected. R\&D tax credits do not offer a "quick fix" for states seeking to stimulate regional economic growth through entrepreneurship (nor will investment tax credits spark a rapid decline in the number of expected growth outcomes from startups). Instead, our cross-sectional results suggest that regional variation, and innovation and entrepreneurship initiatives, likely are stronger contributors to near term growth in the formation rates of high-growth potential startups. And, the impact of $R \& D$ and investment tax incentives compound to substantial levels (albeit in opposite directions) over a ten-year period.

terms impact the composition of entrepreneurship generated (i.e., its extensive margin), while beyond the scope of this paper is likewise an important subject for future research. 


\section{References}

Acemoglu, D., Akcigit, U., Alp, H., Bloom, N., \& Kerr, W. (2018). Innovation, reallocation, and growth. American Economic Review, 108(11), 3450-3491. doi:10.1257/aer.20130470

Acs, Z. J., Braunerhjelm, P., Audretsch, D. B., \& Carlsson, B. (2009). The knowledge spillover theory of entrepreneurship. Small Business Economics, 32(1), 15-30.

Aghion, P., Bloom, N., Blundell, R., Griffith, R., \& Howitt, P. (2005). Competition and innovation: An inverted-U relationship*. The Quarterly Journal of Economics, 120(2), 701728. doi:10.1093/qje/120.2.701

Andersson, M., \& Henrekson, M. (2015). Local competitiveness fostered through local institutions for entrepreneurship. The Oxford Handbook of Local Competitiveness, , 145190.

Arrow, K. J. (1962). Economic welfare and the allocation of resources for invention., 609-625.

Atanassov, J., \& Liu, X. (2019). Can corporate income tax cuts stimulate innovation? Journal of Financial and Quantitative Analysis, , 1-88. doi:10.1017/S0022109019000152

Auerbach, A. J., \& Summers, L. H. (1979). The investment tax credit: An evaluation. Unpublished manuscript.

Babina, T., \& Howell, S. (2018). Entrepreneurial spillovers from corporate R\&D. IDEAS Working Paper Series from RePEc,

Barnes, B. G., Harp, N. L., \& Oler, D. (2014). Evaluating the SDC mergers and acquisitions database. The Financial Review, 49(4), 793-821. Retrieved from http://www.econis.eu/PPNSET?PPN=815245416

Bartik, T. J. (2017). A new panel database on business incentives for economic development offered by state and local governments in the united states. https://research.upjohn.org/reports/225: W.E. Upjohn Institute for Employment Research.

Bartik, T. J. (2018). "But for" percentages for economic development incentives: What percentage estimates are plausible based on the research literature?

Bartik, T. J., \& Hollenbeck, K. (2012). An analysis of the employment effects of the washington high technology business and occupation $(\mathrm{B} \& \mathrm{O})$ tax credit: Technical report. Upjohn Institute Working Paper, 12-187

Bartik, T., \& Eberts, R. (2012). The roles of tax incentives and other business incentives in local economic development. The oxford handbook of urban economics and planning. 2012, pp. 634-54 (pp. 634-654)

Belenzon, S., Chatterji, A. K., \& Daley, B. (2017). Eponymous entrepreneurs. American Economic Review, 107(6), 1638-1655. doi:10.1257/aer.20141524 
Belenzon, S., Chatterji, A., \& Daley, B. (2018). Choosing between growth and glory. (No. w24901).

Bell, J. R., Wilbanks, J. E., \& Hendon, J. R. (2013). Examining the effectiveness of state funded angel investor tax credits: Initial empirical analysis. Small Business Institute Journal, 9(2), 23.

Bloom, N., Griffith, R., \& Van Reenen, J. (2002). Do R\&D tax credits work? evidence from a panel of countries 1979-1997.

Branstetter, L. G., \& Sakakibara, M. (2002). When do research consortia work well and why? evidence from japanese panel data. The American Economic Review, 92(1), 143-159. doi:10.1257/000282802760015649

Bronzini, R., \& Piselli, P. (2016). The impact of R\&D subsidies on firm innovation. Research Policy, 45(2), 442-457. doi:10.1016/j.respol.2015.10.008

Bruce, D. (2000). Effects of the united states tax system on transitions into selfemployment." Labour Economics, 7(5), 545-574.

Bruhn, M., Karlan, D., \& Schoar, A. (2018). The impact of consulting services on small and medium enterprises: Evidence from a randomized trial in Mexico. Journal of Political Economy, 126(2), 635-687. doi:10.1086/696154

Buss, T. F. (2001). The effect of state tax incentives on economic growth and firm location decisions: An overview of the literature. Thousand Oaks, CA: Sage Publications. doi:10.1177/089124240101500108

Chirinko, R. S., \& Wilson, D. J. (2006). State investment tax incentives: What are the facts? Federal Reserve Bank of San Francisco, Working Paper Series, , 25.000. doi:10.24148/wp2006-49

Chirinko, R. S., \& Wilson, D. J. (2008). State investment tax incentives: A zero-sum game? Journal of Public Economics, 92(12), 2362-2384. doi:10.1016/j.jpubeco.2008.07.005

Churchwell, C."Q. SDC: M\&amp;A database". baker library - fast answers.\&nbsp; Retrieved from http://asklib.library.hbs.edu/faq/47760.

Cohen, L., Diether, K., \& Malloy, C. (2013). Misvaluing innovation. New York, N.Y. : doi:10.1093/rfs/hhs183

Cullen, J. B., \& Gordon, R. (2006). Tax reform and entrepreneurial activity. Tax Policy and the Economy, 20, 41-71. doi:10.1086/tpe.20.20061904

Dechezlepretre, A., Einiö, E., Martin, R., Nguyen, K., \& Reenen, J. (2016). Do tax incentives for research increase firm innovation? an $R D$ design for $R \& D$ Centre for Economic Performance, London School of Economics and Political Science.

Delgado, M., Porter, M. E., \& Stern, S. (2016). Defining clusters of related industries. Journal of Economic Geography, 16(1), 1-38. doi:10.1093/jeg/lbv017 
Douglas Holtz-Eakin, David Joulfaian, \& Harvey S. Rosen. (1994). Entrepreneurial decisions and liquidity constraints. The RAND Journal of Economics, 25(2), 334-347.

doi: $10.2307 / 2555834$

Fazio, C., Guzman, J., Murray, F., \& Stern, S. (2016). A new view of the skew: Quantitative assessment of the quality of American entrepreneurship. Kauffman Foundation New Entrepreneurial Growth, Kansas City, MO: February,

Fehder, D. C., \& Hochberg, Y. V. (2014). Accelerators and the regional supply of venture capital investment. Available at SSRN 2518668,

Fichtner, J. J., \& Michel, A. (2015). Can a research and development tax credit be properly designed for economic efficiency. ().Mercatus Center. Retrieved from Social Science Premium Collection

Gale, W. G., \& Brown, S. (2013). Small business, innovation, and tax policy: A review. Innovation, and Tax Policy: A Review (April 8, 2013),

Gans, J. S., \& Stern, S. (2003). The product market and the market for "ideas": Commercialization strategies for technology entrepreneurs. Research Policy. 32 (2): 333350

Gentry, W. M., \& Hubbard, R. G. (2000). Tax policy and entrepreneurial entry. American Economic Review, 90(2), 283-287.

Gentry, W. M., \& Hubbard, R. G. (2004). "Success taxes", entrepreneurial entry, and innovation. Cambridge, Mass: National Bureau of Economic Research. Retrieved from http://papers.nber.org/papers/w10551.pdf

Gonzalez-Uribe, J., \& Paravisini, D. (2017). How sensitive is young firm investment to the cost of outside equity? Unpublished manuscript.

Gonzalez-Uribe, J., \& Leatherbee, M. (2018). The effects of business accelerators on venture performance: Evidence from start-up Chile. Review of Financial Studies, 31(4), 1566-1603. doi:10.1093/rfs/hhx103

Goulding, C. R., Bonafé, A., \& Tomiko, L. The R\&D tax credit aspects of SaaS start-ups. Available online at: https://www.rdtaxsavers.com/articles/SaaS-Start-Ups

Grossman, G. M., \& Helpman, E. (1991). Trade, knowledge spillovers, and growth. European Economic Review. 35 (2-3): 517-526

Gurley-Calvez, T., \& Bruce, D. (2013). Do tax rate cuts encourage entrepreneurial entry? Journal of Entrepreneurship and Public Policy, 2(2), 178-202.

Guzman, J., \& Stern, S. (2015). Where is silicon valley? Science, 347(6222), 606-609. doi:10.1126/science.aaa0201

Guzman, J., \& Stern, S. (2016). The state of American entrepreneurship: New estimates of the quantity and quality of entrepreneurship for 15 US states, 1988-2014. NBER Working Paper No. w22095 
Guzman, J., \& Stern, S. (2017). Nowcasting and placecasting entrepreneurial quality and performance. In Measuring entrepreneurial businesses: Current knowledge and challenges. Eds. John Haltiwanger, Erik Hurst, Javier Miranda, and Antoinette Schoar. University of Chicago Press.

Hall, B., \& Van Reenen, J. (2000). How effective are fiscal incentives for R\&D? A review of the evidence. Research Policy, 29(4-5), 449-469.

Haltiwanger, J., Jarmin, R. S., \& Miranda, J. (2013). Who creates jobs? small versus large versus young. The Review of Economics and Statistics, 95(2), 347-361. doi:10.1162/REST_a_00288

Hearn, J. C., Lacy, T. A., \& Warshaw, J. B. (2014). State research and development tax credits. Economic Development Quarterly, 28(2), 166-181. doi:10.1177/0891242413517135

Hendon, J. R., Bell, J. R., Blair, B., \& Martin, D. K. (2012). State-funded angel investor tax credits. Journal of Entrepreneurship and Public Policy, 1(1), 50-62. doi:10.1108/20452101211208353

Hirshleifer, D., Hsu, P., \& Li, D. (2013). Innovative efficiency and stock returns. Journal of Financial Economics. 107 (3): 632-654.

Hochberg, Y. V. (2016). Accelerating entrepreneurs and ecosystems. Innovation Policy and the Economy, 16, 25-51.

Holtz-Eakin, D. (1995). Should small businesses be tax-favored? National Tax Journal, 48(3), 387-395.

Holtz-Eakin, D. (2000). Public policy toward entrepreneurship. Small Business Economics, 15(4), 283-291.

Jaffe, A. B. (1986). Technological opportunity and spillovers of R\&D. The American Economic Review. 76 (5): 984-1001.

Jeffry Netter, Mike Stegemoller, \& M. Babajide Wintoki. (2011). Implications of data screens on merger and acquisition analysis: A large sample study of mergers and acquisitions from 1992 to 2009. The Review of Financial Studies, 24(7), 2316-2357. doi:10.1093/rfs/hhr010

Joseph R. Bell, \& Jeff B. Woodmansee. (2016). Seeding venture capital: Insights into state-bystate equity tax credit legislation. The Journal of Private Equity, 19(2), 34-42. doi:10.3905/jpe.2016.19.2.034

Katz, M. L. (1986). An analysis of cooperative research and development. The Rand Journal of Economics. 17 (4): 527-543.

Lanahan, L., \& Feldman, M. P. (2018). Approximating exogenous variation in R\&D: Evidence from the kentucky and north carolina SBIR state match programs. Review of Economics and Statistics, 100(4), 740-752. doi:10.1162/rest_a_00681

Lerner, J. (2009). Boulevard of broken dreams. Princeton: Princeton University Press. 
Lokshin, B., \& Mohnen, P. (2007). Measuring the effectiveness of R\&D tax credits in the netherlands. SSRN Working Paper \#1133572.

Lucking, B. (2019). Do R\&D tax credits create jobs?. Working Paper.

Mansfield, E. (1986). Patents and innovation: An empirical study. Management Science, 32(2), 173-181. doi:10.1287/mnsc.32.2.173

Miller, C. R., \& Richard, B. (2010). The policy diffusion of the state R\&D investment tax credit. State \& Local Government Review, 42(1), 22-35. doi:10.1177/0160323X10364748

Mills, K., \& McCarthy, B. (2016). The state of small business lending: Innovation and technology and the implications for regulation. Harvard Business School Entrepreneurial Management Working Paper, (17-042), 17-042.

Moretti, E., \& Wilson, D. J. (2013). State incentives for innovation, star scientists and jobs: Evidence from biotech. Federal Reserve Bank of San Francisco, Working Paper Series, , 155. doi:10.24148/wp2013-17

Moretti, E., \& Wilson, D. J. (2014). State incentives for innovation, star scientists and jobs: Evidence from biotech. Journal of Urban Economics, 79, 20-38.

doi:10.1016/j.jue.2013.07.002

Mukherjee, A., Singh, M., \& Žaldokas, A. (2017). Do corporate taxes hinder innovation? Journal of Financial Economics, 124(1), 195-221. doi:10.1016/j.jfineco.2017.01.004

Pm Romer. (1990). Endogenous technological change. Chicago]:

Pugsley, B. W., \& Hurst, E. (2011). What do small businesses do? Brookings Papers on Economic Activity, 43(2), 73-142.

Ramalho, R., Shleifer, A., Djankov, S., McLiesh, C., \& Ganser, T. (2010). The effect of corporate taxes on investment and entrepreneurship. American Economic Journal: Macroeconomics, 2(3), 31-64.

Rao, N. (2013). Do tax credits stimulate R\&D spending. The Effect of the R\&D Tax Credit in its First Decade.NYU's Wagner School of Public Service,

Reynolds, P. D., Hay, M., \& Camp, S. M. (1999). Global entrepreneurship monitor. Kansas City, Missouri: Kauffman Center for Entrepreneurial Leadership,

Richard E. Kihlstrom, \& Jean-Jacques Laffont. (1979). A general equilibrium entrepreneurial theory of firm formation based on risk aversion. Journal of Political Economy, 87(4), 719748. doi:10.1086/260790

Rosenberg, J. W., \& Marron, D. B. (2015). Tax policy and investment by startups and innovative firms. SSRN Working Paper \#2573259. 
Ryan A. Decker, John Haltiwanger, Ron S. Jarmin, \& Javier Miranda. (2016). Declining business dynamism: What we know and the way forward. The American Economic Review, 106(5), 203-207. doi:10.1257/aer.p20161050

Ryan Decker, John Haltiwanger, Ron Jarmin, \& Javier Miranda. (2014). The role of entrepreneurship in US job creation and economic dynamism. The Journal of Economic Perspectives, 28(3), 3-24. doi:10.1257/jep.28.3.3

Schoar, A. (2010). The divide between subsistence and transformational entrepreneurship. Innovation Policy and the Economy, 10(1), 57-81.

Schumpeter, J. (1942). A.(1942) Capitalism, Socialism and Democracy. New York,

Timothy J. Bartik. A new business incentives database

Tuomi, K., \& Boxer, B. (2015). The costs and benefits of early-stage business tax credits: A case study of two US states. Venture Capital, 17(3), 263-270. doi:10.1080/13691066.2015.1051757

Weiner, J. (2009). State business tax incentives: Examining evidence of their effectiveness. Boston: Federal Reserve Bank of Boston.

Wilson, D. J. (2009). Beggar Thy Neighbor? The In-State, Out-Of-State, And Aggregate Effects Of R\&D Tax Credits. The Review of Economics and Statistics, 91(2), 431-436. doi:10.1162/rest.91.2.431

Wilson, D. J. (2005). The rise and spread of state R\&D tax credits. FRBSF Economic Letter, (2005)

Wu, Y. (2005). The effects of state R\&D tax credits in stimulating private R\&D expenditure: A cross-state empirical analysis. Journal of Policy Analysis and Management: The Journal of the Association for Public Policy Analysis and Management, 24(4), 785-802.

Wu, Y. (2008). State R\&D tax credits and high-technology establishments. Economic Development Quarterly, 22(2), 136-148. doi:10.1177/0891242408316728

Zhao, B., \& Ziedonis, R. H. (2012) .State governments as financiers of technology startups: Implications for firm performance. SSRN Working Paper. 
Table 1: Entrepreneurial Quality Logit Model

All Startups Founded Between 1988 to 2006

Dependent Variable: IPO or Acquisition within 6 Years Incidence Rate Ratios Reported

$\begin{array}{lc} & (1) \\ \text { Eponymous } & 0.259^{* * * *} \\ & (0.0257) \\ \text { Short Name } & 1.883 * * * \\ & (0.0406) \\ \text { Corporation } & 4.916 * * * \\ & (0.204) \\ \text { Trademark } & 4.280^{* * * *} \\ \text { Delaware Patent Interactions } & (0.264) \\ \text { Delaware } & 33.21 * * * \\ & (1.059) \\ \text { Patent } & 49.44 * * *\end{array}$

Delaware and Patent $\quad 211.9 * * *$

Industry Descriptors

Local Industries $\quad 0.465^{* * * *}$

$(0.0300)$

Traded Industries $1.152 * * *$

(0.0326)

Biotechnology $2.354 * * *$

$\begin{array}{lr}\text { E-Commerce } & 1.075\end{array}$

Medical Devices $\quad 1.297 * * *$

(0.0664)

Semiconductor $1.862 * * *$

State FE

Yes

$\begin{array}{lc}\mathrm{N} & 18916895 \\ \mathrm{pseudo} \text { R-sq } & 0.264\end{array}$

We report the incidence rate-ratios of a logit model performed on all companies born between 1988 and 2008 in 34 US states. The predicted value of this regression is our measure of quality for individual firms, which we aggregate into regional statistics. The outcome variable of the regression is Growth a binary variable equal to 1 if the firm achieves an IPO or acquisition within 6 years and 0 otherwise. The regressors are all binary measures observed at or near the time of firm registration. Patent and Trademark are indicators developed by matching our data to USPTO records. They are equal to 1 of owns a patent or trademark within one year of founding (both granted and applied). All other measures are developed directly from our business registration records. Robust standard errors in parenthesis. The regression and data are described in further detail in Guzman and Stern (2016). $* * * \mathrm{p}<.01$ 
Table 2: Summary Statistics

\begin{tabular}{lccc}
\hline & Count & Mean & Std. Dev. \\
\hline Startup Cartography Project & & & \\
$\quad$ Obs (Quantity of Entrepreneurship) & 30093 & 397.107 & 1947.699 \\
$\quad$ RECPI (Quality-adjusted Quantity of & 30093 & 0.358 & 2.03 \\
Entrepreneurship) & 30093 & 0.637 & 6.529 \\
$\quad$ REAI (Ecosystem Effects) & & & \\
Panel Database of Incentives and Taxes (PDIT) & 29224 & 0.461 & 0.499 \\
$\quad$ Has R\&D Credit & 29372 & 0.383 & 0.486 \\
$\quad$ Has Investment Credit & &
\end{tabular}

Table 3: The Impact of R\&D Tax Credits on Regional Entrepreneurship

\begin{tabular}{|c|c|c|c|}
\hline & $\begin{array}{c}(1) \\
\operatorname{Ln}(\mathrm{Obs})\end{array}$ & $\begin{array}{c}(2) \\
\operatorname{Ln}(\text { RECPI })\end{array}$ & $\begin{array}{c}(3) \\
\text { REAI }\end{array}$ \\
\hline \multicolumn{4}{|l|}{ Model I: Naive Model (no controls) } \\
\hline Has R\&D Credit & $\begin{array}{c}0.477 * * * \\
(0.102)\end{array}$ & $\begin{array}{c}0.642 * * * \\
(0.104)\end{array}$ & $\begin{array}{r}-0.137 * * \\
(0.0697)\end{array}$ \\
\hline \multicolumn{4}{|c|}{ Model II: Difference-In-Differences (county, year F.E.) } \\
\hline Has R\&D Credit & $\begin{array}{l}0.0745^{*} \\
(0.0389)\end{array}$ & $\begin{array}{l}0.0760 * * \\
(0.0376)\end{array}$ & $\begin{array}{r}-0.0265 \\
(0.159)\end{array}$ \\
\hline \multicolumn{4}{|c|}{ Model III: Difference-In-Differences + County Level Pre-Trends } \\
\hline Has R\&D Credit & $\begin{array}{l}0.0927 * * \\
(0.0366)\end{array}$ & $\begin{array}{l}0.104 * * * \\
(0.0381)\end{array}$ & $\begin{array}{r}-0.0973 \\
(0.139)\end{array}$ \\
\hline \multicolumn{4}{|c|}{ Model IV: Difference-In-Differences + State GDP } \\
\hline Has R\&D Credit & $\begin{array}{l}0.0651^{*} \\
(0.0337)\end{array}$ & $\begin{array}{l}0.0641 * * \\
(0.0302)\end{array}$ & $\begin{array}{l}-0.0193 \\
(0.163)\end{array}$ \\
\hline $\log ($ State GDP $)$ & $\begin{array}{c}1.016 * * * \\
(0.116)\end{array}$ & $\begin{array}{c}1.293 * * * \\
(0.125)\end{array}$ & $\begin{array}{l}-0.776 \\
(0.856)\end{array}$ \\
\hline $\begin{array}{l}\text { Model V: Difference-In-Differences }+ \\
\text { Years Before Credit (Negative values) }\end{array}$ & $\begin{array}{c}0.00242 \\
(0.00726)\end{array}$ & $\begin{array}{c}0.00802 \\
(0.00695)\end{array}$ & $\begin{array}{r}-0.00246 \\
(0.0719)\end{array}$ \\
\hline Has R\&D Credit & $\begin{array}{l}-0.0281 \\
(0.0426)\end{array}$ & $\begin{array}{l}-0.0332 \\
(0.0451)\end{array}$ & $\begin{array}{r}-0.0252 \\
(0.173)\end{array}$ \\
\hline Has R\&D Credit X Years After Credit & $\begin{array}{l}0.0230 * * * \\
(0.00744)\end{array}$ & $\begin{array}{l}0.0224 * * * \\
(0.00698)\end{array}$ & $\begin{array}{r}0.000648 \\
(0.0151)\end{array}$ \\
\hline
\end{tabular}

County level pre-trends is the predicted value of entrepreneurship for each county based on the non-credit years Standard errors clustered two ways by county and year.

$* \mathrm{p}<.1, * * \mathrm{p}<.05, * * * \mathrm{p}<.01$ 
Table 4: The Impact of Investment Tax Credits on Regional Entrepreneurship

\begin{tabular}{lccc}
\hline \hline & $(1)$ & $(2)$ & $(3)$ \\
& $\mathrm{Ln}(\mathrm{Obs})$ & $\mathrm{Ln}(\mathrm{RECPI})$ & $\mathrm{REAI}$ \\
\hline Model I: Naive Model (no controls) & $0.705^{* * *}$ & $0.352^{* *}$ & -0.0586 \\
Has Investment Credit & $(0.123)$ & $(0.141)$ & $(0.115)$ \\
Model II: Difference-In-Differences (county, year F.E.) & & & \\
Has Investment Credit & -0.0527 & $-0.0912^{* *}$ & 0.104 \\
Model III: Difference-In-Differences + County Level Pre-Trends & $(0.0385)$ & $(0.0392)$ & $(0.150)$ \\
Has Investment Credit & -0.0465 & $-0.0874 * *$ & 0.264 \\
Model IV: Difference-In-Differences + State GDP & $(0.0380)$ & $(0.0394)$ & $(0.181)$ \\
Has Investment Credit & -0.0331 & $-0.0661 *$ & 0.0901 \\
& $(0.0333)$ & $(0.0348)$ & $(0.143)$ \\
Log(State GDP) & & & \\
Model V: Difference-In-Differences + Pre/Post Time Effects & $0.938 * * *$ & $1.199 * * *$ & -0.664 \\
Years Before Credit (Negative values) & $(0.140)$ & $(0.146)$ & $(0.812)$ \\
& 0.0154 & 0.0122 & -0.0172 \\
Has Investment Credit & $(0.0175)$ & $(0.0147)$ & $(0.0617)$ \\
& & & \\
Has Investment Credit X Years After Credit & -0.0397 & -0.0359 & 0.220 \\
& $(0.0565)$ & $(0.0554)$ & $(0.161)$ \\
\hline \hline
\end{tabular}

County level pre-trends is the predicted value of entrepreneurship for each county based on the non-credit years Standard errors clustered two ways by county and year.

$* \mathrm{p}<.1, * * \mathrm{p}<.05, * * * \mathrm{p}<.01$ 


\section{FIGURES}

Figure 1: Distribution of Tax Credits

\section{R\&D Credits By St at es at Beginning and End}

1990

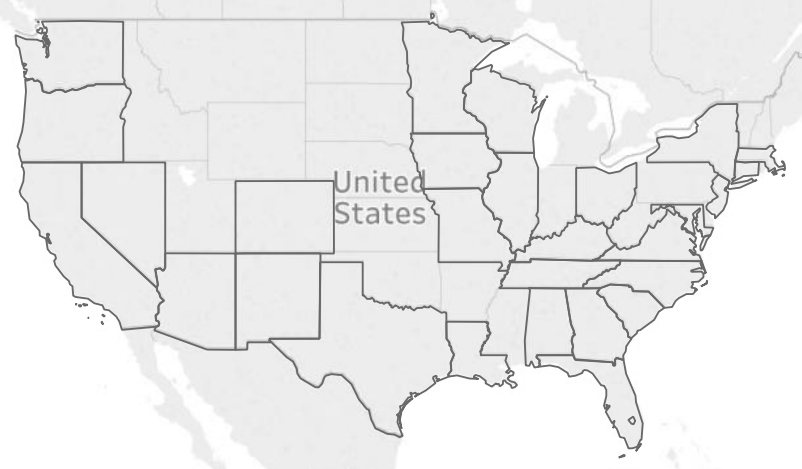

Mexico

Year

2010

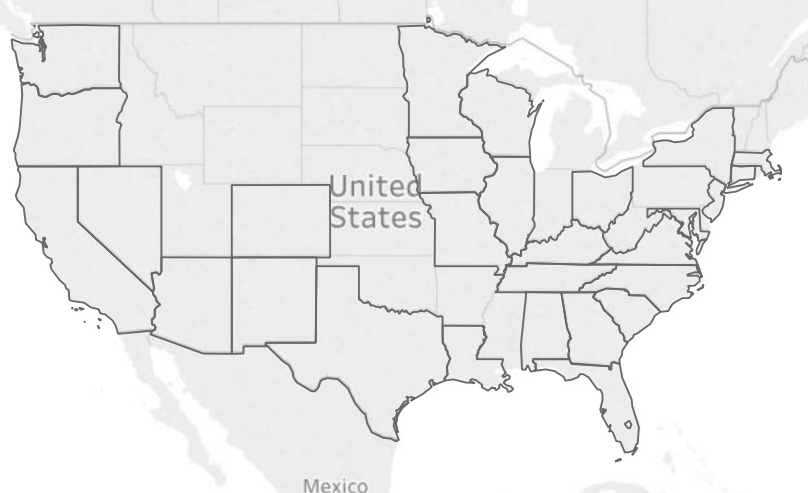

Invest ment Credits By States at Beginning and End

1990

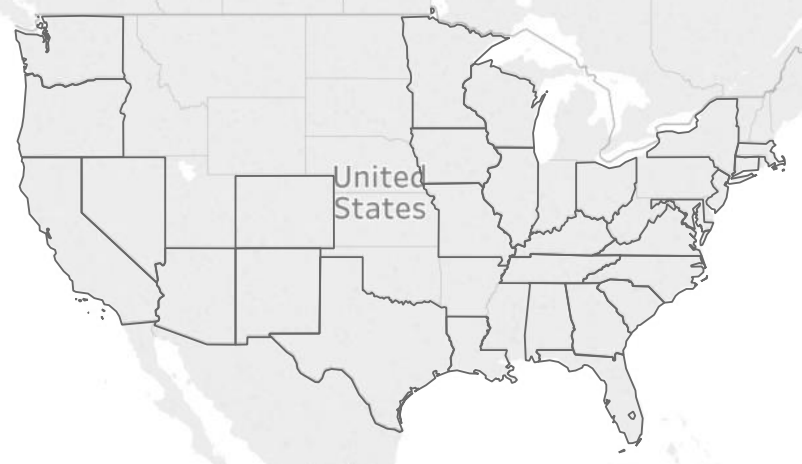

Mexico
Year

2010

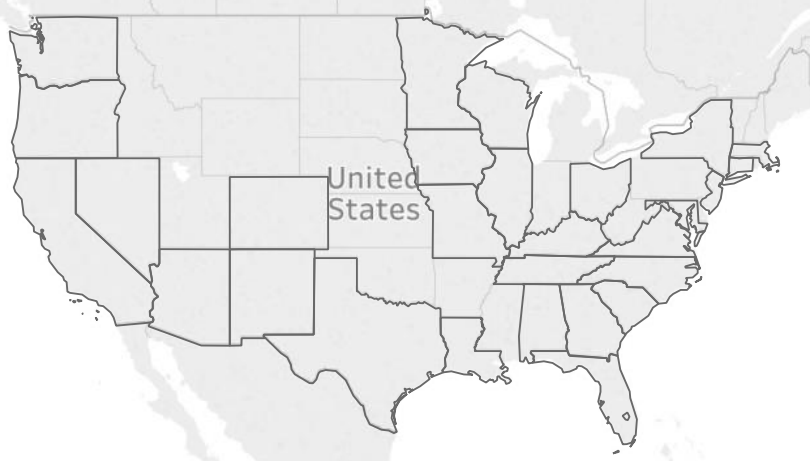

Mexico

\section{Quality of Ent repreneurship by County}

1990

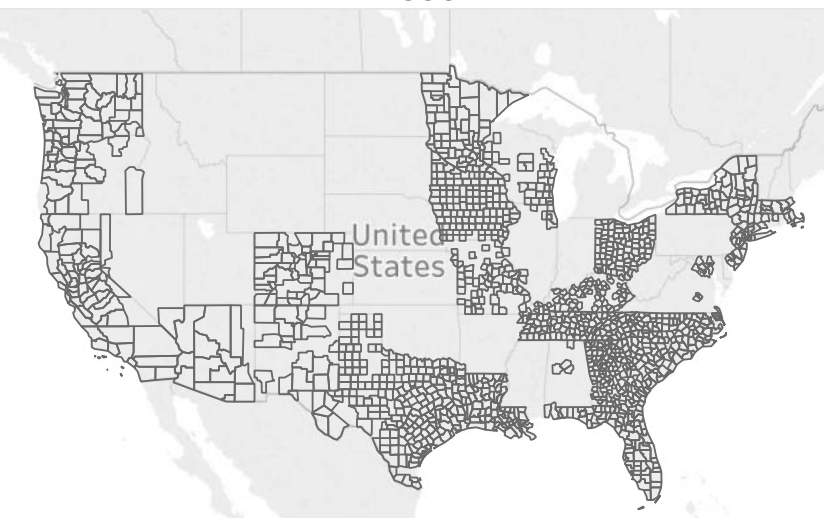

Mexico
Year

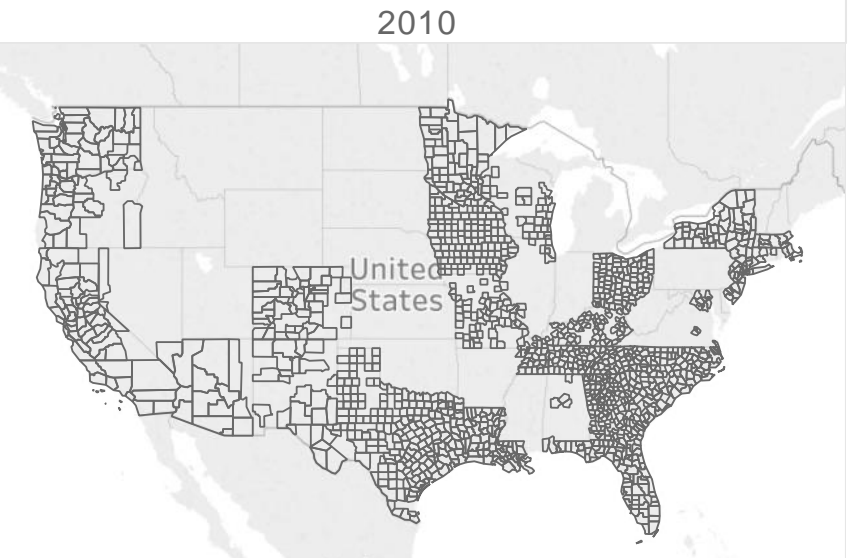


Figure 2: Year-by-Year Effects of R\&D Tax Credits on Entrepreneurship
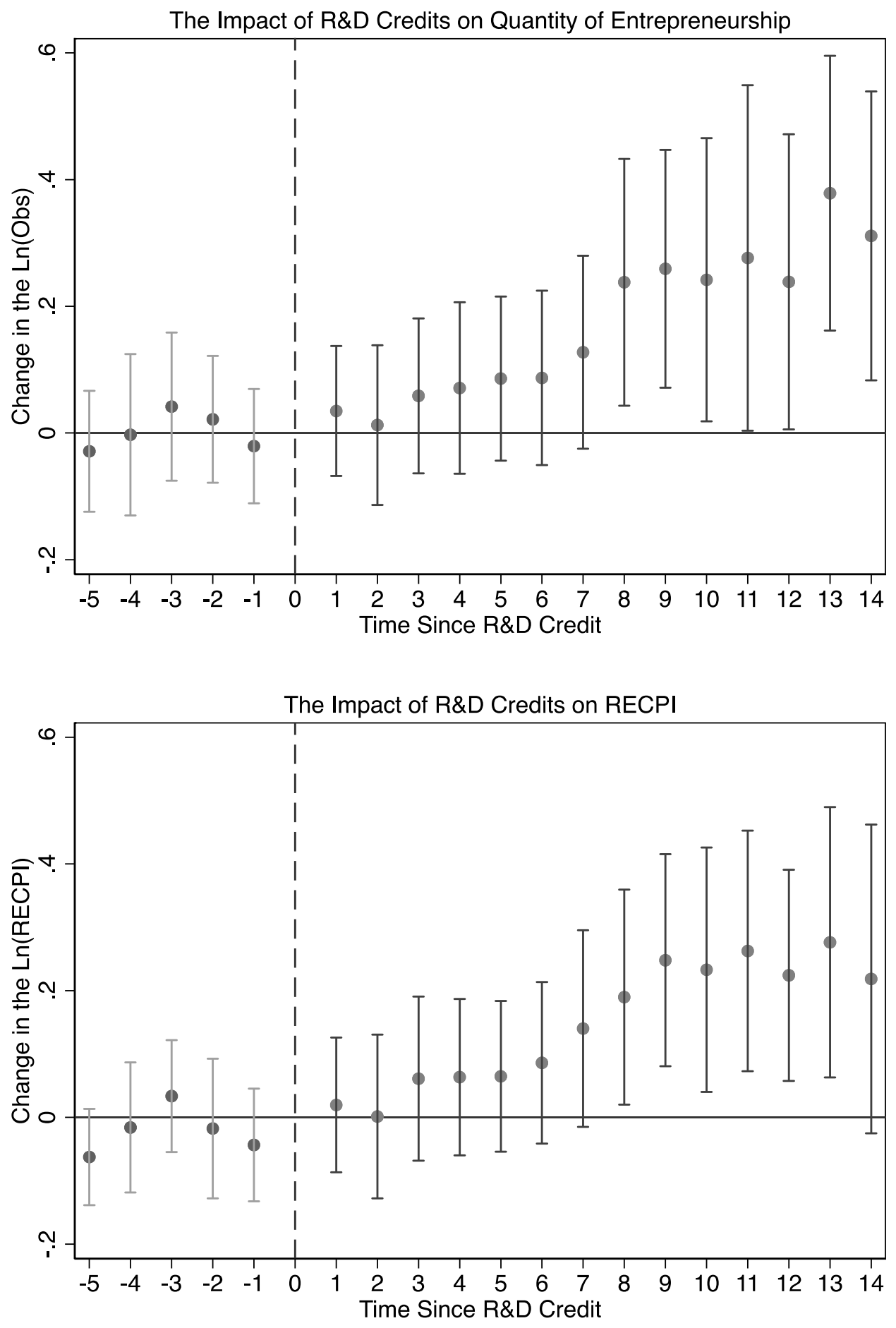
Figure 3: Year-by-Year Effects of Investment Tax Credits on Entrepreneurship
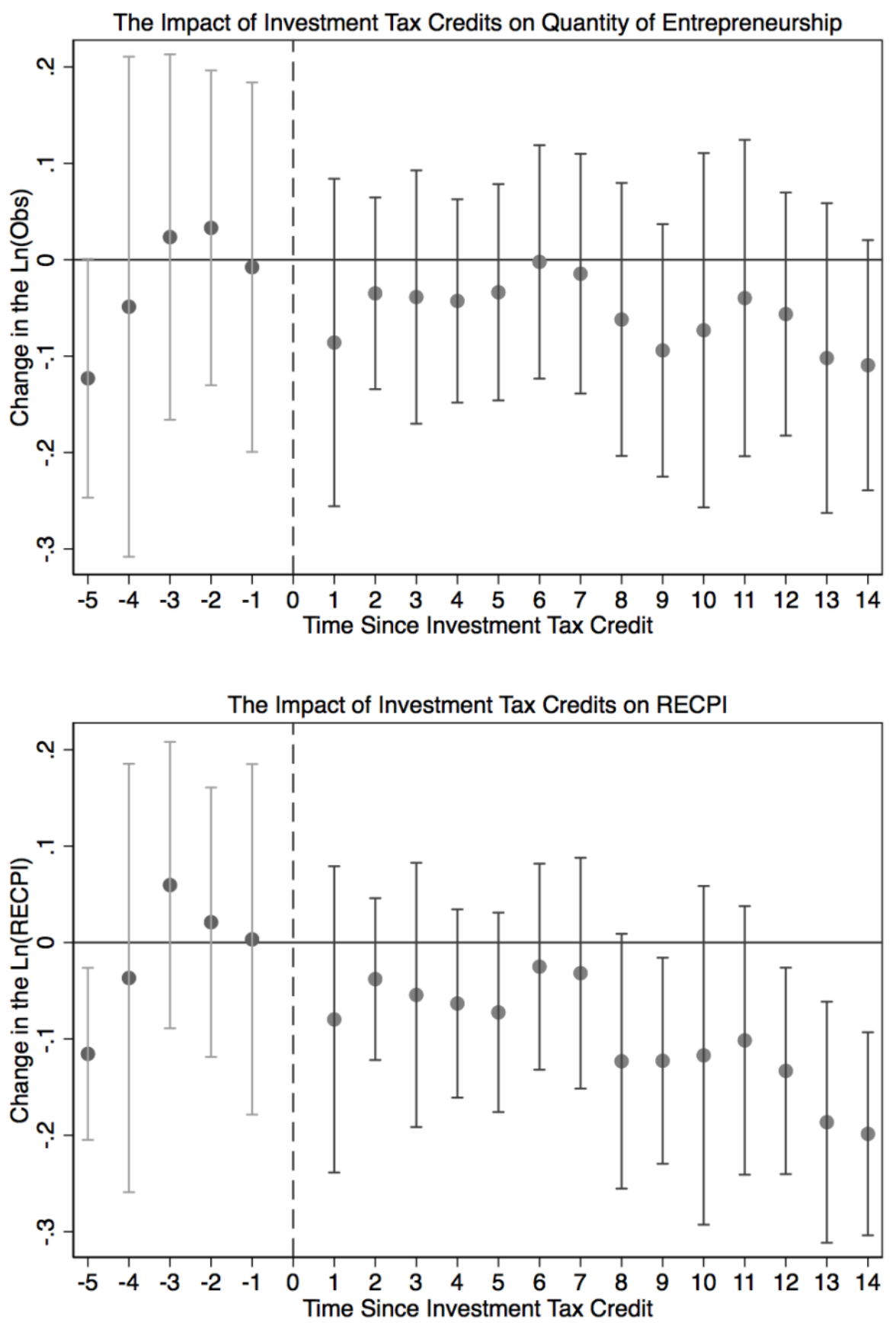


\section{Appendix}

Table A1: Summary Statistics of Firm-Level Dataset

\begin{tabular}{|c|c|c|c|}
\hline Outcome Variable & Source & Mean & Std Dev \\
\hline Growth & SDC Platinum & 0.00033 & 0.01825 \\
\hline \multicolumn{4}{|c|}{ Corporate Form Observables } \\
\hline Corporation & Bus. Reg. Records & 0.52 & 0.50 \\
\hline Delaware & Bus. Reg. Records & 0.031 & 0.172 \\
\hline \multicolumn{4}{|l|}{ Name-Based Observables } \\
\hline Short Name & Bus. Reg. Records & 0.49 & 0.63 \\
\hline Eponymous & Bus. Reg. Records & 0.0679 & 0.2516 \\
\hline \multicolumn{4}{|c|}{ Intellectual Property Observables } \\
\hline Patent & USPTO & 0.0016 & 0.0404 \\
\hline Trademark & USPTO & 0.0012 & 0.0351 \\
\hline \multicolumn{4}{|l|}{ US CMP Observables (1) } \\
\hline Local & Estimated from name & 0.19 & 0.40 \\
\hline Traded (2) & Estimated from name & 0.135 & 0.341 \\
\hline Traded Resource Int. & Estimated from name & 0.535 & 0.499 \\
\hline Biotech Sector & Estimated from name & 0.002 & 0.044 \\
\hline Ecommerce Sector & Estimated from name & 0.052 & 0.222 \\
\hline IT Sector & Estimated from name & 0.022 & 0.146 \\
\hline Medical Dev. Sector & Estimated from name & 0.028 & 0.166 \\
\hline $\begin{array}{c}\text { Semiconductor Sector } \\
\text { Observations }\end{array}$ & Estimated from name & $\begin{array}{c}0.000 \\
29,961,838 \\
\end{array}$ & 0.020 \\
\hline
\end{tabular}

(1) US CMP Cluster Dummies are estimated by using a sample of $10 \mathrm{M}$ firms and comparing the incidence of each word in the name within and outside a cluster, then selecting the words that have the highest relative incidence as informative of a cluster. Firms get a value of 1 if they have any of those words in their name. The procedure is explained in detail in our Data Appendix.

(2) Note that there are also firms that we cannot associate with local nor traded industries. 
Table A2: The Impact of R\&D Tax Credits on Regional Entrepreneurship

\begin{tabular}{|c|c|c|c|}
\hline & $\begin{array}{c}(1) \\
\operatorname{Ln}(\mathrm{Obs}) \\
\end{array}$ & $\begin{array}{c}(2) \\
\operatorname{Ln}(\text { RECPI })\end{array}$ & $\begin{array}{c}(3) \\
\text { REAI }\end{array}$ \\
\hline \multicolumn{4}{|l|}{ Model I: Naive Model (no controls) } \\
\hline Has R\&D Credit & $\begin{array}{c}0.506 * * * \\
(0.0898)\end{array}$ & $\begin{array}{c}0.661 * * * \\
(0.101)\end{array}$ & $\begin{array}{l}-0.142 * * \\
(0.0715)\end{array}$ \\
\hline Has Investment Credit & $\begin{array}{c}0.695 * * * \\
(0.119)\end{array}$ & $\begin{array}{c}0.345^{* *} \\
(0.135)\end{array}$ & $\begin{array}{l}-0.0678 \\
(0.113)\end{array}$ \\
\hline \multicolumn{4}{|l|}{ Model II: Difference-In-Differences (county, year F.E.) } \\
\hline Has R\&D Credit & $\begin{array}{l}0.0694 * \\
(0.0389)\end{array}$ & $\begin{array}{c}0.0693 * \\
(0.0374)\end{array}$ & $\begin{array}{c}-0.00903 \\
(0.162)\end{array}$ \\
\hline Has Investment Credit & $\begin{array}{l}-0.0426 \\
(0.0386)\end{array}$ & $\begin{array}{c}-0.0822 * * \\
(0.0404)\end{array}$ & $\begin{array}{c}0.106 \\
(0.150)\end{array}$ \\
\hline \multicolumn{4}{|c|}{ Model III: Difference-In-Differences + County Level Pre-Trends } \\
\hline Has R\&D Credit & $\begin{array}{c}0.0854 * * \\
(0.0363)\end{array}$ & $\begin{array}{c}0.0952 * * \\
(0.0382)\end{array}$ & $\begin{array}{l}-0.0854 \\
(0.146)\end{array}$ \\
\hline Has Investment Credit & $\begin{array}{l}-0.0441 \\
(0.0362)\end{array}$ & $\begin{array}{c}-0.0909 * * \\
(0.0407)\end{array}$ & $\begin{array}{l}-0.0306 \\
(0.154)\end{array}$ \\
\hline \multicolumn{4}{|l|}{ Model IV: Difference-In-Differences + State GDP } \\
\hline Has R\&D Credit & $\begin{array}{l}0.0626^{*} \\
(0.0345)\end{array}$ & $\begin{array}{c}0.0605 * \\
(0.0310)\end{array}$ & $\begin{array}{c}-0.00398 \\
(0.167)\end{array}$ \\
\hline Has Investment Credit & $\begin{array}{l}-0.0240 \\
(0.0345)\end{array}$ & $\begin{array}{c}-0.0583 \\
(0.0370)\end{array}$ & $\begin{array}{l}0.0920 \\
(0.145)\end{array}$ \\
\hline $\log ($ State GDP $)$ & $\begin{array}{c}0.933 * * * \\
(0.123)\end{array}$ & $\begin{array}{c}1.196 * * * \\
(0.130)\end{array}$ & $\begin{array}{l}-0.691 \\
(0.835)\end{array}$ \\
\hline $\begin{array}{l}\text { Model V: Difference-In-Differences }+ \text { Pre/Post } 7 \\
\text { Years Before R\&D Credit (Negative values) }\end{array}$ & $\begin{array}{r}-0.000820 \\
(0.00877)\end{array}$ & $\begin{array}{c}0.00451 \\
(0.00785)\end{array}$ & $\begin{array}{l}-0.00875 \\
(0.0758)\end{array}$ \\
\hline Has R\&D Credit & $\begin{array}{l}-0.0322 \\
(0.0499)\end{array}$ & $\begin{array}{l}-0.0392 \\
(0.0494)\end{array}$ & $\begin{array}{l}0.0108 \\
(0.179)\end{array}$ \\
\hline Has R\&D Credit X Years After Credit & $\begin{array}{r}0.0228 * * * \\
(0.00786)\end{array}$ & $\begin{array}{l}0.0222 * * * \\
(0.00722)\end{array}$ & $\begin{array}{l}-0.00137 \\
(0.0158)\end{array}$ \\
\hline Years Before Investment Credit (Negative values) & $\begin{array}{l}0.0185 \\
(0.0165)\end{array}$ & $\begin{array}{c}0.0139 \\
(0.0138)\end{array}$ & $\begin{array}{l}-0.0147 \\
(0.0648)\end{array}$ \\
\hline Has Investment Credit & $\begin{array}{l}-0.0555 \\
(0.0572)\end{array}$ & $\begin{array}{c}-0.0501 \\
(0.0541)\end{array}$ & $\begin{array}{c}0.221 \\
(0.165)\end{array}$ \\
\hline Has Investment Credit X Years After Credit & $\begin{array}{r}-0.00446^{*} \\
(0.00262)\end{array}$ & $\begin{array}{c}-0.00988 * * * \\
(0.00265)\end{array}$ & $\begin{array}{l}-0.0128 \\
(0.0137)\end{array}$ \\
\hline
\end{tabular}

County level pre-trends is the predicted value of entrepreneurship for each county based on the non-credit years Standard errors clustered two ways by county and year/ $* \mathrm{p}<.1, * * \mathrm{p}<.05, * * * \mathrm{p}<.01$ 